\title{
Port Capability Evaluation from the Perspective of Supply Chain
}

\author{
Leijie Zhang $\mathbb{D}^{1},{ }^{1}$ Sijia $Q \mathbf{u}^{2}$ and Jin Dai $\mathbb{D}^{3}$ \\ ${ }^{1}$ School of Economics \& Management, Shanghai Maritime University, Shanghai, China \\ ${ }^{2}$ ANJI-CEVA Logistics Co., Ltd., Shanghai, China \\ ${ }^{3}$ Institute of Logistics Science and Engineering, Shanghai Maritime University, Shanghai, China \\ Correspondence should be addressed to Leijie Zhang; jeryzhang@163.com
}

Received 21 October 2021; Accepted 15 December 2021; Published 31 December 2021

Academic Editor: Tingsong Wang

Copyright (C) 2021 Leijie Zhang et al. This is an open access article distributed under the Creative Commons Attribution License, which permits unrestricted use, distribution, and reproduction in any medium, provided the original work is properly cited.

\begin{abstract}
Today's ports have become an important node in the global supply chain. It is particularly important to make a scientific assessment of the comprehensive capabilities of the port and to provide a reference for the long-term development of the port. From the perspective of the supply chain, this article first selects the evaluation indicators that affect the port's capabilities from four aspects of port resource ownership, control management, comprehensive services, and innovation-driven aspect. Secondly, we use the expert scoring method to judge the importance of the evaluation indicators and build a scientific and independent port capacity evaluation system from the perspective of the supply chain. Then, this paper uses the analytic hierarchy process to determine the weight coefficients of each evaluation index and uses the gray cluster analysis method of the triangular whitening weight function based on the center point to establish a qualitative and quantitative port capacity evaluation model from the perspective of the supply chain. Finally, we take a port in Northeast Asia as an example to conduct an empirical analysis to verify the feasibility of the port capacity evaluation system and model from the perspective of the supply chain constructed in this paper. The research results of this article can well analyze the port's resource ownership, control and management capabilities, comprehensive service capabilities, and innovation-driven capabilities and provide a practical and effective theoretical basis for the port's key development directions.
\end{abstract}

\section{Introduction}

With the in-depth development of world economic globalization and regional economic integration, trade exchanges between countries have continued to expand and cargo transportation has become increasingly frequent [1]. Maritime transportation is responsible for more than $80 \%$ of the global cargo trade. As a hub of land and water transportation, ports have become an important node in the supply chain network. The traditional functions of loading, unloading, handling, and storage have been unable to meet the needs of port development.

The current economy has gradually transformed into the postindustrial era, and the development of modern ports has shown some new trends. Large-scale, deep-water specialization and expansion of value-added services are the future development directions of ports. The rapid development of the global supply chain integrating logistics, business flow, information flow, and capital flow has also made customers increasingly demanding that ports provide integrated supply chain services and continue to use traditional growth, profitability, and competition. Looking at the development of ports from a competitive perspective, simply evaluating and analyzing the capability level of the port from the perspective of port throughput, profit, and domestic and foreign rankings are very detrimental to the long-term development of the port. Therefore, it is particularly important to establish a port capacity evaluation system based on the global supply chain, to make a scientific assessment of the port's comprehensive capacity level, and to provide a reference for the long-term development of the port.

Modern ports from the perspective of the supply chain should rely on good ownership (hardware and software facilities) to obtain the best control capabilities and rely on ownership and control capabilities (internal and external resources) to obtain the best service capabilities (customer service level) and the strongest innovation capabilities (competitiveness and adaptability). 
The research on the port evaluation index system started relatively early abroad, and its research focused on the analysis and discussion of the factors affecting the port capacity level and established a corresponding evaluation index system based on the actual situation. Bird [2,3] analyzed the factors that affect the core capabilities of the port from the perspective of geography and established a corresponding evaluation index system based on the specific conditions of the Victoria Harbour. Bird generalized the evaluation index system of Victoria Harbour and derived a more general port evaluation model and index system. Kenyon [4] and Mayer [5] expanded Bird's research from the perspectives of economics and sociology and analyzed the factors that influence the port's core capabilities in terms of port transportation convenience, accessibility, port labor efficiency, and labor costs. Yap and Lam [6] affirmed the previous scholars' research and evaluation, while starting from the social environment and human geographic environment, and further expanded research on the port core competence evaluation system and evaluation method. Haezendonck and Notteboom [7] believed that the important factors affecting the port capacity are the productivity level and product quality. The influencing factors such as accessibility of the hinterland, port reputation, and reliability play a vital role in enhancing the attractiveness of the port's sources of goods. The service quality was evaluated and analyzed, and seven factors including port location, port management, port transit time, port rate, and facility availability were selected for analysis. Banomyong [8] took Incheon Port in Korea as an example, and a comprehensive evaluation index system was established for Incheon Port by considering the service level, container throughput, total container size, cargo potential, policy transparency, supportiveness, etc. Tongzon [9] put forward port rates, port operation efficiency and level, adaptability to the external environment, the convenience and reliability of the hinterland, the depth of the waterway, and the degree of service differentiation can be used as indicators to evaluate the level of port capabilities. Ha [10] mainly considers the port service aspect, proposes the port location, port expenses, port management, port turnaround time, facility availability, consumer convenience, port information availability, and other indicators, and constructs the evaluation index system.

\section{Analysis of Port Development and Influencing Factors}

The development of a port is mainly affected by four major capability factors, namely, the port's resource ownership, port's control and management capabilities, port's comprehensive service capabilities, and port's innovation-driven capabilities.

2.1. Port Resource-Possessing Capacity. The port's resource ownership refers to the port enterprise's possession of production resources, human resources, and financial resources. Among them, production resources mainly include port hardware facilities and equipment, which is an important foundation for port production and operation [11]. The area of the port, the length of the shoreline, the number of berths, and the number of machinery will directly affect the volume and process of port operations; human resources include employees of different functions, different types of work, and different levels recruited by the port, which are the basics of port operation and management conditions. Financial resources include fixed assets, liquidity, option shares, and other financial assets held by the port, which are the material basis for the operation and development of the port. A port enterprise's resources are not as good as possible. Excessive ownership will result in a large amount of idle assets and slow capital turnover and bring a heavy burden to the enterprise. However, if the scale of ownership is too small, it will also be difficult to meet the needs of port production and operation, and it will be difficult for certain production and operation activities to proceed normally. Port enterprises should pay more attention to the quality of ownership on the basis of the quantity and scale of ownership.

2.2. Port Control and Management Capabilities. The control and management capability of a port refers to the control and management of internal and external resources by port enterprises, including market control, information control, and financial control [12]. Market control is mainly reflected in the scale of bulk commodity sources, the scale of global procurement and sales, the scale of industrial linkage, and the scale of diversified operations. The port's information control and management level is also an important factor affecting the port's capabilities. As an important node in the global supply chain network, the port has tens of thousands of data and information flows. If such a huge information flow is improperly controlled and managed, it will inevitably affect information transmission. The patency and timeliness of the port will affect the operation efficiency of the entire port. A port company must continuously strengthen its own control and management capabilities; otherwise, even if it has large-scale resources, it will be controlled by other upstream and downstream companies. Port enterprises must continuously improve their influence and voice in the supply chain system, realize the control of the entire supply chain, and optimize the operation of the supply chain.

2.3. Comprehensive Port Service Capabilities. The comprehensive service capability of a port refers to the level of service provided by port enterprises to customers, including logistics services, trade services, and financial services. The service capability of a port is the main manifestation of the level of port operation and management. The service capability of a port enterprise is directly related to the customer's satisfaction and loyalty to the port brand and indirectly affects the efficiency of port operations. Port enterprises should change the traditional service model of "receiving money by sitting on the ground," focusing on customers, vigorously developing a comprehensive service model integrating logistics, trade, and finance, expanding the development of high-end value-added services, and further improving the ability to serve customers. 
2.4. Port Innovation-Driving Capability. The innovationdriven capability of the port refers to the deepening of scientific and technological innovation, strategic innovation, and institutional innovation by port enterprises in order to adapt to the needs of customers under the concept of global supply chain, with innovation awareness as the driving force. Technological innovation has a profound impact on the development of ports and even the development of the country, and strategic innovation and institutional innovation are also important driving forces for the transformation and development of port enterprises. The enhancement of the port's innovative capabilities will not only enable enterprises to adapt to the macroeconomic environment at home and abroad but also actively lead the trend of industry development and promote the enhancement of port enterprises' competitiveness.

\section{Construction of the Port Capability Evaluation System}

3.1. Preliminary Construction of the Evaluation System. Port capacity evaluation is a multiobjective decision-making process, and there are many factors that affect the overall decision-making and the degree of influence is also different. Therefore, it is necessary to classify various indicators to form a multiobjective, multilevel comprehensive evaluation index system [13].

Relevant studies have shown that the use of a combination of subjective and objective methods to screen evaluation indicators will make the constructed evaluation indicator system more scientific and more credible [14]. Therefore, this article uses subjective expert scoring method combined with [1].

3.2. Evaluation Index Screening Steps. Because the port capacity evaluation index system constructed in this paper is very large, only the third-level index under the second-level index of production resources is taken as an example to analyze the specific selection steps of port evaluation index. In the initial evaluation index system, there are 7 three-level indicators at the level of production resource indicators, namely, port area, shoreline length, number of berths, berthing capacity, passing capacity, number of loading and unloading machinery, and loading and unloading of mechanical load capacity. According to the screening process and method described above, the initial indicators of the port capability evaluation system from the perspective of the supply chain are screened. The specific steps are as follows, and the flowchart is shown Figure 1.

Step 1: use the average to reflect the importance of each indicator to the entire system and calculate the average score of 20 experts on the 7 indicators. Step 2: use standard deviation to reflect the degree of dispersion of expert scoring judgments, and calculate the standard deviation of expert scoring for 7 indicators. Step 3: use the coefficient of variation to verify the concentration of expert opinions again, and calculate the coefficient of variation of the 7 indicators. Step 4: use the Kendall Harmony Coefficient to verify the credibility and consistency of expert scores. Step 5: independence analysis, which means using SPSS (Statistical Product and Service Solutions) software, the original 7 indicators are divided into 6 components, and get their variance contribution rate and component matrix.

Through the calculation and analysis of the above five steps, it can be seen that under the production resource index as the secondary evaluation index, the three-level evaluation index of loading and unloading machinery load capacity can be eliminated and the remaining simplified three-level evaluation indicators are port area and shoreline length, number of berths, berthing capacity, passing capacity, and number of loading and unloading machinery. Under this step, the screening of other three-level evaluation indicators can be completed, and a more streamlined and scientific port capacity evaluation system can be established.

\section{Construction of the Port Capability Evaluation Model}

4.1. Determination of the Weights of Port Capacity Evaluation Indicators. Through the analytic hierarchy process method [15], the judgment matrix, relative weight coefficient, maximum eigenvalue, and consistency ratio of each evaluation index can be calculated, and finally, the weight coefficients of each port capacity evaluation index are shown in Table 1.

\subsection{Construction of the Port Capability Evaluation Model.} Gray clustering refers to the method of dividing some observation indicators or observation objects into several definable categories according to the gray incidence matrix [16]. At the same time, it is also a method that combines quantitative analysis and qualitative analysis, which improves the accuracy and completeness of the evaluation process to a certain extent. Gray whitening weight function clustering is mainly used to analyze whether the evaluation object belongs to different categories set in advance, so as to obtain the ability level of the evaluation object [17]. The advantage of gray whitening weight function cluster analysis method is that it has a small demand for sample data in the analysis process and does not have strict requirements for the statistical distribution of data [18]. It is suitable for dealing with the problems of missing data or difficult-to-quantify statistics.

However, the traditional whitening weight function has a large amount of calculation and can only calculate the gray interval of the object to be evaluated. When the objects to be evaluated belong to the same gray interval at the same time, it is impossible to accurately judge which is better and which is not conducive to subsequent evaluation and analysis [19]. Therefore, this paper uses the triangular whitening weight function based on the center point for gray cluster analysis [20]. 


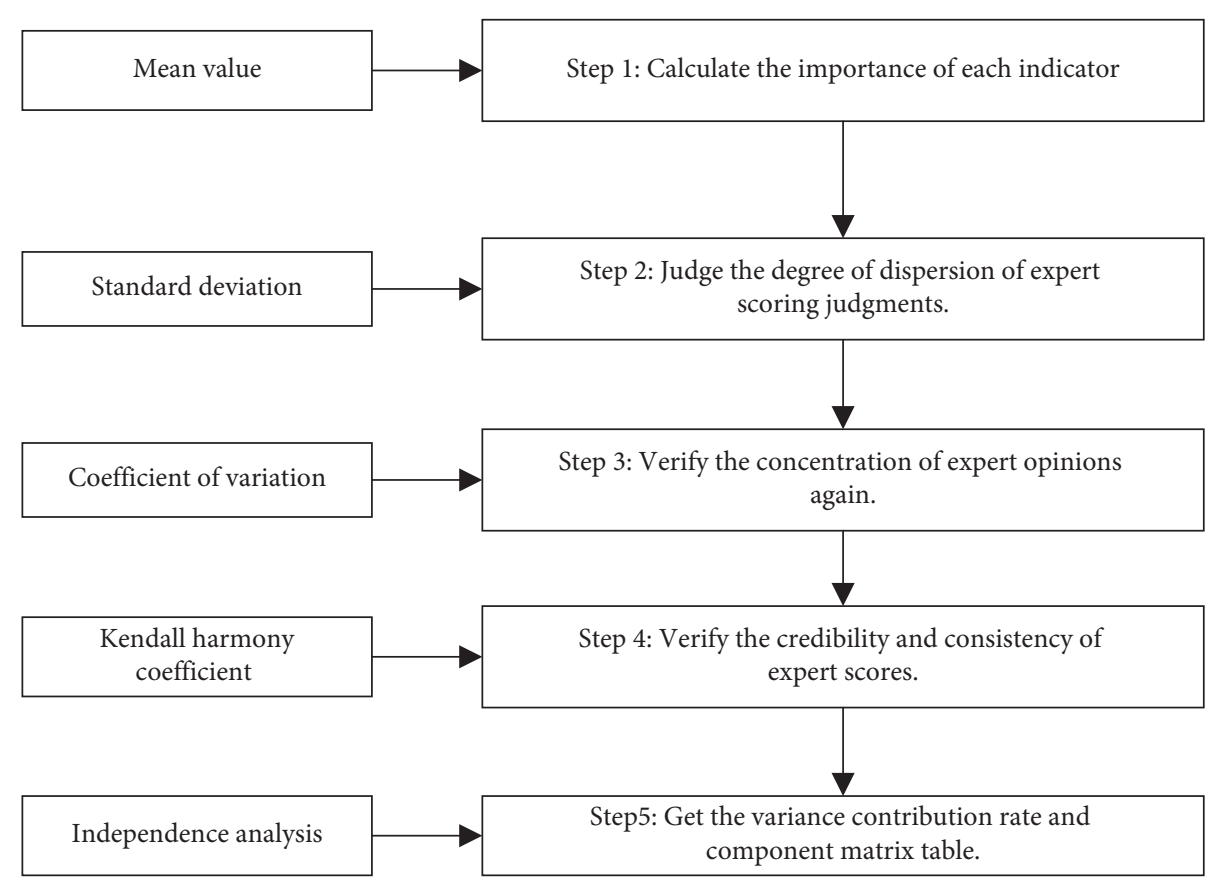

Figure 1: Calculation steps of each index component.

\section{Empirical Analysis}

5.1. Status of Port A Development. Port A is located in Northeast Asia, with a port area of 10.4 square kilometers. It has 94 modern professional production berths for containers, crude oil, automobiles, bulk mines, grain, coal, ro-ro, etc., of which 73 berths are above 10,000 tons. The comprehensive throughput capacity reaches 280 million tons per year, and the maximum berthing capacity reaches 400,000 tons. In 2016, the cargo throughput of Port A was approximately 370 million tons, an increase of $17.6 \%$ over 2010.

As of the end of 2015, Port A has opened 108 container liner routes, including 83 foreign trade routes and 15 trunk routes, ocean trunk routes directly to major trade areas in the world and the route network covers more than 300 ports in 160 countries and regions at home and abroad. There are 13 internal branch line service networks covering 13 ports around the Bohai Sea and the Yellow Sea, which has greatly improved the cargo transfer and distribution capacity of Port A.

\subsection{Evaluation of Port A Capacity}

5.2.1. Determination of the Evaluation Index Value and Gray Interval. According to the relevant data provided by the research team of Port $A$, the actual values of the evaluation indicators established for Port A are shown in Table 2. According to the gray clustering model built in Section 4.2, the port's capability level is divided into four gray categories: poor, medium, good, and excellent. By consulting each year's China Port Yearbook, browsing the financial statements of each port, looking up relevant domestic and foreign research documents, and consulting port industry experts, we can determine the value of each gray range, as shown in Table 3.

5.2.2. Whitening Weight Function Calculation. According to Table 3, the center point of each gray class interval can be determined as the turning point, the triangular whitening weight function based on the center point can be constructed, and the whitening weight function of each quantitative index can be obtained, as shown in Table 4 .

5.2.3. Membership Calculation. For quantitative indicators, the membership degree of each evaluation indicator is the whitening coefficient of each indicator corresponding to each gray category. For example, the port area of Port A is 10.4 square kilometers, and substituting it into the whitening weight function of each gray category corresponding to the port area index obtained in Section 5.2.2, four gray scales of the evaluation index of port area can be obtained. The membership degrees of the classes are, respectively, $0,0.65$, 0.35 , and 0 ; for qualitative indicators, the membership degree is obtained by dividing the number of votes of experts by the total number of experts. For example, in terms of the reproducibility of the last indicator innovation system, among the 20 experts, there are 0 people who voted poorly, 1 person who voted, 15 people who voted well, and 4 people who voted excellently. The membership degrees of the four gray categories of the evaluation index of the replicability of the innovation system are, respectively, $0,0.05,0.75$, and 0.20 .

In the same way, the membership degrees of other threelevel evaluation indicators can be obtained. Due to the complex calculation and large amount of calculation, this 
TABle 1: Port capacity evaluation index weight.

\begin{tabular}{|c|c|c|c|c|c|}
\hline First-level indicator & $\begin{array}{c}\text { Weight } \\
\text { coefficient }\end{array}$ & Secondary indicators & $\begin{array}{l}\text { Weight } \\
\text { coefficient }\end{array}$ & Third-level indicators & $\begin{array}{l}\text { Weight } \\
\text { coefficient }\end{array}$ \\
\hline \multirow{13}{*}{$\begin{array}{l}\text { Resource possession } \\
\text { A1 }\end{array}$} & \multirow{13}{*}{1} & \multirow{6}{*}{ Production resources $\mathrm{B} 1$} & \multirow{6}{*}{0.4000} & Port area $\mathrm{C} 1$ & 0.0638 \\
\hline & & & & Shoreline length C2 & 0.0248 \\
\hline & & & & Number of berths C3 & 0.0405 \\
\hline & & & & Berthing capacity C4 & 0.0992 \\
\hline & & & & Passing ability $\mathrm{C} 5$ & 0.1257 \\
\hline & & & & Number of loading and unloading machinery C6 & 0.0461 \\
\hline & & \multirow{4}{*}{ Human resources B2 } & \multirow{4}{*}{0.2000} & Proportion of ordinary workers C7 & 0.0193 \\
\hline & & & & Proportion of compound talents C8 & 0.0568 \\
\hline & & & & Overall labor productivity C9 & 0.1239 \\
\hline & & & & Operating income $\mathrm{C} 10$ & 0.1984 \\
\hline & & \multirow{3}{*}{ Financial resources B3 } & \multirow{3}{*}{0.4000} & Operating costs $\mathrm{C} 11$ & 0.1155 \\
\hline & & & & Financing amount $\mathrm{C} 12$ & 0.0343 \\
\hline & & & & Financial license ownership C13 & 0.0518 \\
\hline \multirow{13}{*}{$\begin{array}{l}\text { Control management } \\
\text { A2 }\end{array}$} & \multirow{13}{*}{1} & \multirow{6}{*}{ Market control B4 } & \multirow{6}{*}{0.5889} & Cargo throughput C14 & 0.2498 \\
\hline & & & & Proportion of international supply $\mathrm{C} 15$ & 0.0452 \\
\hline & & & & Commodity supply scale C16 & 0.1025 \\
\hline & & & & Global procurement and sales scale $\mathrm{C} 17$ & 0.0905 \\
\hline & & & & Diversified business scale $\mathrm{C} 18$ & 0.0684 \\
\hline & & & & Number of cooperative institutions C19 & 0.0324 \\
\hline & & \multirow{3}{*}{ Information control B5 } & \multirow{3}{*}{0.1593} & Proportion of online business C20 & 0.0859 \\
\hline & & & & Information acquisition channels C21 & 0.0261 \\
\hline & & & & Access to information quality $\mathrm{C} 22$ & 0.0474 \\
\hline & & \multirow{4}{*}{ Financial control B6 } & \multirow{4}{*}{0.2519} & Net asset yield C23 & 0.0969 \\
\hline & & & & Net profit growth rate $\mathrm{C} 24$ & 0.0969 \\
\hline & & & & Assets and liabilities C25 & 0.0361 \\
\hline & & & & Asset turnover rate C26 & 0.0221 \\
\hline \multirow{9}{*}{ General service A3 } & \multirow{9}{*}{1} & \multirow{4}{*}{ Logistics services B7 } & \multirow{4}{*}{0.5485} & Logistics service price C27 & 0.0681 \\
\hline & & & & Logistics service quality C28 & 0.2574 \\
\hline & & & & Logistics cargo loss rate $\mathrm{C} 29$ & 0.1544 \\
\hline & & & & Logistics punctuality C30 & 0.0686 \\
\hline & & \multirow{3}{*}{ Trade service B8 } & \multirow{3}{*}{0.2409} & Trade volume growth rate $\mathrm{C} 31$ & 0.0803 \\
\hline & & & & Trade service quality $\mathrm{C} 32$ & 0.1606 \\
\hline & & & & Supply chain financial service level C33 & 0.1312 \\
\hline & & Financial services B9 & 0.2106 & Customer financing business amount C34 & 0.0289 \\
\hline & & & & Customer financing service satisfaction C35 & 0.0504 \\
\hline & & & & Proportion of scientific research investment C36 & 0.0538 \\
\hline & & & & Technology judgment and tracking ability C37 & 0.0967 \\
\hline & & Technological innovation & & Maturity of R\&D tools and methods C38 & 0.1586 \\
\hline & & $\mathrm{B} 10$ & 0.539 & $\begin{array}{c}\text { New technology promotion and application } \\
\text { ability C39 }\end{array}$ & 0.1706 \\
\hline & & & & Number of special plans C40 & 0.0592 \\
\hline & & & & $\begin{array}{l}\text { Industry intelligence analysis investment } \\
\text { accounted for C41 }\end{array}$ & 0.0285 \\
\hline Innoyation-driven A4 & 1 & Strategic innovation B11 & 0.2973 & Industry situation judgment accuracy C42 & 0.0479 \\
\hline Innovation-driven A4 & 1 & & & Operability of strategic planning C43 & 0.1385 \\
\hline & & & & Sustainability of strategic planning C44 & 0.0824 \\
\hline & & & & $\begin{array}{l}\text { The marketization process of the innovation } \\
\text { system C45 }\end{array}$ & 0.0480 \\
\hline & & System innovation $\mathrm{B} 12$ & 0.1638 & $\begin{array}{l}\text { Administrative efficiency of the innovation } \\
\text { system C46 }\end{array}$ & 0.0675 \\
\hline & & & & $\begin{array}{c}\text { International compliance of the innovation } \\
\text { system C47 }\end{array}$ & 0.0177 \\
\hline & & & & Reproducibility of the innovation system C48 & 0.0307 \\
\hline
\end{tabular}


TABLe 2: Values for each indicator of Port A.

\begin{tabular}{|c|c|c|c|}
\hline Index & Value & Unit & Nature \\
\hline Port area $\mathrm{C} 1$ & 10.4 & Square kilometers & Quantitative \\
\hline Shoreline length C2 & 61.2 & Kilometer & Quantitative \\
\hline Number of berths C3 & 94 & Individual & Quantitative \\
\hline Berthing capacity $\mathrm{C} 4$ & 40 & Ten thousand tons & Quantitative \\
\hline Passing ability C5 & 2.8 & Billion tons & Quantitative \\
\hline Number of loading and unloading machinery C6 & 241 & Tower & Quantitative \\
\hline Proportion of ordinary workers C7 & 62 & $\%$ & Quantitative \\
\hline Proportion of compound talents C8 & 33 & $\%$ & Quantitative \\
\hline Overall labor productivity C9 & 9.8 & Ten thousand CNY/person & Quantitative \\
\hline Operating income $\mathrm{C} 10$ & 87.6 & Hundred million CNY & Quantitative \\
\hline Operating costs $\mathrm{C} 11$ & 72.4 & Hundred million CNY & Quantitative \\
\hline Financing amount $\mathrm{C} 12$ & 54 & Hundred million CNY & Quantitative \\
\hline Financial license ownership $\mathrm{C} 13$ & 43 & Leaf & Quantitative \\
\hline Cargo throughput C14 & 3.7 & Billion tons & Quantitative \\
\hline Proportion of international supply $\mathrm{C} 15$ & 39.1 & $\%$ & Quantitative \\
\hline Commodity supply scale $\mathrm{C} 16$ & - & - & Qualitative \\
\hline Global procurement and sales scale $\mathrm{C} 17$ & - & - & Qualitative \\
\hline Diversified business scale $\mathrm{C} 18$ & - & - & Qualitative \\
\hline Number of cooperative institutions C19 & 518 & - & Quantitative \\
\hline Proportion of online business C20 & 64 & $\%$ & Quantitative \\
\hline Information acquisition channels C21 & - & - & Qualitative \\
\hline Access to information quality $\mathrm{C} 22$ & - & - & Qualitative \\
\hline Net asset yield C23 & 3.47 & $\%$ & Quantitative \\
\hline Net profit growth rate $\mathrm{C} 24$ & 1.16 & $\%$ & Quantitative \\
\hline Assets and liabilities C25 & 45.53 & $\%$ & Quantitative \\
\hline Asset turnover rate C26 & 30.9 & $\%$ & Quantitative \\
\hline Logistics service price C27 & 380 & $\mathrm{CNY/TEU}$ & Quantitative \\
\hline Logistics service quality C28 & - & - & Qualitative \\
\hline Logistics cargo loss rate C29 & 0.08 & $\%$ & Quantitative \\
\hline Logistics punctuality C30 & 98.6 & $\%$ & Quantitative \\
\hline Trade volume growth rate $\mathrm{C} 31$ & 23.6 & $\%$ & Quantitative \\
\hline Trade service quality C32 & - & - & Qualitative \\
\hline Supply chain financial service level C33 & - & - & Qualitative \\
\hline Customer financing business amount C34 & 635 & Ten thousand CNY & Quantitative \\
\hline Customer financing service satisfaction C35 & - & - & Qualitative \\
\hline Proportion of scientific research investment C36 & 21 & $\%$ & Quantitative \\
\hline Technology judgment and tracking ability C37 & - & - & Qualitative \\
\hline Maturity of R\&D tools and methods C38 & - & - & Qualitative \\
\hline New technology promotion and application ability C39 & - & - & Qualitative \\
\hline Number of special plans C40 & 42 & - & Quantitative \\
\hline Industry intelligence analysis investment accounted for C41 & 8 & $\%$ & Quantitative \\
\hline Industry situation judgment accuracy $\mathrm{C} 42$ & - & - & Qualitative \\
\hline Operability of strategic planning $\mathrm{C} 43$ & - & - & Qualitative \\
\hline Sustainability of strategic planning C44 & - & - & Qualitative \\
\hline The marketization process of the innovation system $\mathrm{C} 45$ & - & - & Qualitative \\
\hline Administrative efficiency of innovation system C46 & - & - & Qualitative \\
\hline International compliance of the innovation system $\mathrm{C} 47$ & - & - & Qualitative \\
\hline Reproducibility of the innovation system C48 & - & - & Qualitative \\
\hline
\end{tabular}

article uses Matlab programming to achieve the membership degree matrix of each evaluation index as shown in Table 5.

5.2.4. Clustering Coefficient Calculation. Taking the participating vector $V=\left(\begin{array}{lll}1 & 234\end{array}\right)^{T}$ and combining the membership matrix $U_{j}$ obtained in Table 6 , the clustering coefficient of each evaluation index $y_{j}$ can be calculated, as shown in Table 6.
Therefore, combining the weight coefficients of each evaluation index obtained in Section 4.2, the clustering coefficients of Port A's own capabilities, control capabilities, service capabilities, and innovation capabilities can be calculated, as well as the comprehensive clustering coefficients reflecting the overall capability of Port A. The clustering coefficient of Port A's resource holding capacity can be calculated as shown in Table 7 . 
TABLE 3: Gray ranges for each indicator.

\begin{tabular}{|c|c|c|c|c|c|}
\hline Index & Type & Gray range (poor) & Gray range (middle) & Gray range 3 (good) & Gray range 4 (excellent) \\
\hline $\mathrm{C} 1$ & Benefit & $3 \leq x \leq 7$ & $7 \leq x \leq 11$ & $11 \leq x \leq 15$ & $15 \leq x \leq 19$ \\
\hline $\mathrm{C} 2$ & Benefit & $5 \leq x \leq 25$ & $25 \leq x \leq 45$ & $45 \leq x \leq 65$ & $65 \leq x \leq 85$ \\
\hline $\mathrm{C} 3$ & Benefit & $40 \leq x \leq 60$ & $60 \leq x \leq 80$ & $80 \leq x \leq 100$ & $100 \leq x \leq 120$ \\
\hline $\mathrm{C} 4$ & Benefit & $10 \leq x \leq 20$ & $20 \leq x \leq 30$ & $30 \leq x \leq 40$ & $40 \leq x \leq 50$ \\
\hline C5 & Benefit & $0.5 \leq x \leq 1.5$ & $1.5 \leq x \leq 2.5$ & $2.5 \leq x \leq 3.5$ & $3.5 \leq x \leq 4.5$ \\
\hline C6 & Benefit & $100 \leq x \leq 150$ & $150 \leq x \leq 200$ & $200 \leq x \leq 250$ & $250 \leq x \leq 300$ \\
\hline $\mathrm{C} 7$ & Benefit & $80 \geq x \geq 70$ & $70 \geq x \geq 60$ & $60 \geq x \geq 50$ & $50 \geq x \geq 40$ \\
\hline $\mathrm{C} 8$ & Benefit & $20 \leq x \leq 30$ & $30 \leq x \leq 40$ & $40 \leq x \leq 50$ & $50 \leq x \leq 60$ \\
\hline C9 & Benefit & $5 \leq x \leq 7$ & $7 \leq x \leq 9$ & $9 \leq x \leq 11$ & $11 \leq x \leq 13$ \\
\hline $\mathrm{C} 10$ & Benefit & $60 \leq x \leq 70$ & $70 \leq x \leq 80$ & $80 \leq x \leq 90$ & $90 \leq x \leq 100$ \\
\hline $\mathrm{C} 11$ & Benefit & $100 \geq x \geq 90$ & $90 \geq x \geq 80$ & $80 \geq x \geq 70$ & $70 \geq x \geq 60$ \\
\hline $\mathrm{C} 12$ & Benefit & $20 \leq x \leq 40$ & $40 \leq x \leq 60$ & $60 \leq x \leq 80$ & $80 \leq x \leq 100$ \\
\hline $\mathrm{C} 13$ & Benefit & $5 \leq x \leq 20$ & $20 \leq x \leq 35$ & $35 \leq x \leq 50$ & $50 \leq x \leq 65$ \\
\hline $\mathrm{C} 14$ & Benefit & $1 \leq x \leq 2$ & $2 \leq x \leq 3$ & $3 \leq x \leq 4$ & $4 \leq x \leq 5$ \\
\hline $\mathrm{C} 15$ & Benefit & $10 \leq x \leq 20$ & $20 \leq x \leq 30$ & $30 \leq x \leq 40$ & $40 \leq x \leq 50$ \\
\hline $\mathrm{C} 16$ & Benefit & Qualitative & Qualitative & Qualitative & Qualitative \\
\hline $\mathrm{C} 17$ & Benefit & Qualitative & Qualitative & Qualitative & Qualitative \\
\hline $\mathrm{C} 18$ & Benefit & Qualitative & Qualitative & Qualitative & Qualitative \\
\hline $\mathrm{C} 19$ & Benefit & $100 \leq x \leq 300$ & $300 \leq x \leq 500$ & $500 \leq x \leq 700$ & $700 \leq x \leq 900$ \\
\hline $\mathrm{C} 20$ & Benefit & $40 \leq x \leq 50$ & $50 \leq x \leq 60$ & $60 \leq x \leq 70$ & $70 \leq x \leq 80$ \\
\hline $\mathrm{C} 21$ & Benefit & Qualitative & Qualitative & Qualitative & Qualitative \\
\hline $\mathrm{C} 22$ & Benefit & Qualitative & Qualitative & Qualitative & Qualitative \\
\hline $\mathrm{C} 23$ & Benefit & $0 \leq x \leq 1.5$ & $1.5 \leq x \leq 3$ & $3 \leq x \leq 4.5$ & $4.5 \leq x \leq 6$ \\
\hline $\mathrm{C} 24$ & Benefit & $0 \leq x \leq 1$ & $1 \leq x \leq 2$ & $2 \leq x \leq 3$ & $3 \leq x \leq 4$ \\
\hline $\mathrm{C} 25$ & Benefit & $60 \geq x \geq 50$ & $50 \geq x \geq 40$ & $40 \geq x \geq 30$ & $30 \geq x \geq 20$ \\
\hline $\mathrm{C} 26$ & Benefit & $15 \leq x \leq 20$ & $20 \leq x \leq 25$ & $25 \leq x \leq 30$ & $30 \leq x \leq 35$ \\
\hline $\mathrm{C} 27$ & Benefit & $450 \geq x \geq 420$ & $420 \geq x \geq 390$ & $390 \geq x \geq 360$ & $360 \geq x \geq 330$ \\
\hline $\mathrm{C} 28$ & Benefit & Qualitative & Qualitative & Qualitative & Qualitative \\
\hline $\mathrm{C} 29$ & Benefit & $0.2 \geq x \geq 0.15$ & $0.15 \geq x \geq 0.1$ & $0.1 \geq x \geq 0.05$ & $0.05 \geq x \geq 0$ \\
\hline $\mathrm{C} 30$ & Benefit & $96 \leq x \leq 97$ & $97 \leq x \leq 98$ & $98 \leq x \leq 99$ & $99 \leq x \leq 100$ \\
\hline C31 & Benefit & $5 \leq x \leq 15$ & $15 \leq x \leq 25$ & $25 \leq x \leq 35$ & $35 \leq x \leq 45$ \\
\hline $\mathrm{C} 32$ & Benefit & Qualitative & Qualitative & Qualitative & Qualitative \\
\hline $\mathrm{C} 33$ & Benefit & Qualitative & Qualitative & Qualitative & Qualitative \\
\hline $\mathrm{C} 34$ & Benefit & $100 \leq x \leq 300$ & $300 \leq x \leq 500$ & $500 \leq x \leq 700$ & $700 \leq x \leq 900$ \\
\hline $\mathrm{C} 35$ & Benefit & Qualitative & Qualitative & Qualitative & Qualitative \\
\hline $\mathrm{C} 36$ & Benefit & $5 \leq x \leq 10$ & $10 \leq x \leq 15$ & $15 \leq x \leq 20$ & $20 \leq x \leq 25$ \\
\hline $\mathrm{C} 37$ & Benefit & Qualitative & Qualitative & Qualitative & Qualitative \\
\hline $\mathrm{C} 38$ & Benefit & Qualitative & Qualitative & Qualitative & Qualitative \\
\hline C39 & Benefit & Qualitative & Qualitative & Qualitative & Qualitative \\
\hline $\mathrm{C} 40$ & Benefit & $10 \leq x \leq 20$ & $20 \leq x \leq 30$ & $30 \leq x \leq 40$ & $40 \leq x \leq 50$ \\
\hline C41 & Benefit & $3 \leq x \leq 6$ & $6 \leq x \leq 9$ & $9 \leq x \leq 12$ & $12 \leq x \leq 15$ \\
\hline $\mathrm{C} 42$ & Benefit & Qualitative & Qualitative & Qualitative & Qualitative \\
\hline $\mathrm{C} 43$ & Benefit & Qualitative & Qualitative & Qualitative & Qualitative \\
\hline C44 & Benefit & Qualitative & Qualitative & Qualitative & Qualitative \\
\hline $\mathrm{C} 45$ & Benefit & Qualitative & Qualitative & Qualitative & Qualitative \\
\hline $\mathrm{C} 46$ & Benefit & Qualitative & Qualitative & Qualitative & Qualitative \\
\hline $\mathrm{C} 47$ & Benefit & Qualitative & Qualitative & Qualitative & Qualitative \\
\hline $\mathrm{C} 48$ & Benefit & Qualitative & Qualitative & Qualitative & Qualitative \\
\hline
\end{tabular}

In the same way, the clustering coefficients of other secondary evaluation indicators can be obtained, as shown in Table 8.

\subsection{Capacity Analysis and Suggestions for Port A}

5.3.1. Evaluation and Analysis of Port A Capacity. According to the calculation of the various evaluation indicators of Port A using the gray clustering method in
Section 5.2, the comprehensive evaluation map of port capacity level of Port A can be obtained as shown in Figure 2 and Figure 3. The ability-level distribution and ranking diagram of various secondary indicators, as shown in Figure 4 , denote the diagram of the proportion of ability levels of each three-level indicator in Port A.

It can be seen from Figure 2 that the overall capability level of Port A is relatively good and the four major capability levels are more evenly distributed. Among them, Port A has the most excellent comprehensive service 
TABLE 4: Albino functions for each quantitative indicator.

\begin{tabular}{|c|c|c|c|c|}
\hline Index & Gray range 1 (poor) & Gray range 2 (middle) & Gray range 3 (good) & Gray range 4 (excellent) \\
\hline $\mathrm{C} 1$ & $f(-,-, 5,9)$ & $f(5,9,-, 13)$ & $f(9,13,-, 17)$ & $f(13,17,-,-)$ \\
\hline $\mathrm{C} 2$ & $f(-,-, 15,35)$ & $f(15,35,-, 55)$ & $f(35,55,-, 75)$ & $f(55,75,-,-)$ \\
\hline $\mathrm{C} 3$ & $f(-,-, 50,70)$ & $f(50,70,-, 90)$ & $f(70,90,-, 110)$ & $f(90,110,-,-)$ \\
\hline $\mathrm{C} 4$ & $f(-,-, 15,25)$ & $f(15,25,-, 35)$ & $f(25,35,-, 45)$ & $f(35,45,-,-)$ \\
\hline C5 & $f(-,-, 1,2)$ & $f(1,2,-, 3)$ & $f(2,3,-, 4)$ & $f(3,4,-,-)$ \\
\hline C6 & $f(-,-, 125,175)$ & $f(125,175,-, 225)$ & $f(175,225,-, 275)$ & $f(225,275,-,-)$ \\
\hline $\mathrm{C} 7$ & $f(65,75,-,-)$ & $f(55,65,-, 75)$ & $f(45,55,-, 65)$ & $f(-,-, 45,55)$ \\
\hline $\mathrm{C} 8$ & $f(-,-, 25,35)$ & $f(25,35,-, 45)$ & $f(35,45,-, 55)$ & $f(45,55,-,-)$ \\
\hline C9 & $f(-,-, 6,8)$ & $f(6,8,-, 10)$ & $f(8,10,-, 12)$ & $f(10,12,-,-)$ \\
\hline $\mathrm{C} 10$ & $f(-,-, 65,75)$ & $f(65,75,-, 85)$ & $f(75,85,-, 95)$ & $f(85,95,-,-)$ \\
\hline $\mathrm{C} 11$ & $f(85,95,-,-)$ & $f(75,85,-, 95)$ & $f(65,75,-, 85)$ & $f(-,-, 65,75)$ \\
\hline $\mathrm{C} 12$ & $f(-,-, 30,50)$ & $f(30,50,-, 70)$ & $f(50,70,-, 90)$ & $f(70,90,-,-)$ \\
\hline $\mathrm{C} 13$ & $f(-,-, 12.5,27.5)$ & $f(12.5,27.5,-, 42.5)$ & $f(27.5,42.5,-, 57.5)$ & $f(42.5,57.5,-,-)$ \\
\hline $\mathrm{C} 14$ & $f(-,-, 1.5,2.5)$ & $f(1.5,2.5,-, 3.5)$ & $f(2.5,3.5,-, 4.5)$ & $f(3.5,4.5,-,-)$ \\
\hline $\mathrm{C} 15$ & $f(-,-, 15,25)$ & $f(15,25,-, 35)$ & $f(25,35,-, 45)$ & $f(35,45,-,-)$ \\
\hline C19 & $f(-,-, 200,400)$ & $f(200,400,-, 600)$ & $f(400,600,-, 800)$ & $f(600,800,-,-)$ \\
\hline $\mathrm{C} 20$ & $f(-,-, 45,55)$ & $f(45,55,-, 65)$ & $f(55,65,-, 75)$ & $f(65,75,-,-)$ \\
\hline $\mathrm{C} 23$ & $f(-,-, 0.75,2.25)$ & $f(0.75,2.25,-, 3.75)$ & $f(2.25,3.75,-, 5.25)$ & $f(3.75,5.25,-,-)$ \\
\hline $\mathrm{C} 24$ & $f(-,-, 0.5,1.5)$ & $f(0.5,1.5,-, 2.5)$ & $f(1.5,2.5,-, 3.5)$ & $f(2.5,3.5,-,-)$ \\
\hline $\mathrm{C} 25$ & $f(45,55,-,-)$ & $f(35,45,-, 55)$ & $f(25,35,-, 45)$ & $f(-,-, 25,35)$ \\
\hline $\mathrm{C} 26$ & $f(-,-, 17.5,22.5)$ & $f(17.5,22.5,-, 27.5)$ & $f(22.5,27.5,-, 32.5)$ & $f(27.5,32.5,-,-)$ \\
\hline $\mathrm{C} 27$ & $f(405,435,-,-)$ & $f(375,405,-, 435)$ & $f(345,375,-, 405)$ & $f(-,-, 345,375)$ \\
\hline $\mathrm{C} 29$ & $f(0.125,0.175,-,-)$ & $f(0.075,0.125,-, 0.175)$ & $f(0.025,0.075,-, 0.125)$ & $f(-,-, 0.025,0.075)$ \\
\hline $\mathrm{C} 30$ & $f(-,-, 96.5,97.5)$ & $f(96.5,97.5,-, 98.5)$ & $f(97.5,98.5,-, 99.5)$ & $f(98.5,99.5,-,-)$ \\
\hline $\mathrm{C} 31$ & $f(-,-, 10,20)$ & $f(10,20,-, 30)$ & $f(20,30,-, 40)$ & $f(30,40,-,-)$ \\
\hline $\mathrm{C} 34$ & $f(-,-, 200,400)$ & $f(200,400,-, 600)$ & $f(400,600,-, 800)$ & $f(600,800,-,-)$ \\
\hline $\mathrm{C} 36$ & $f(-,-, 7.5,12.5)$ & $f(7.5,12.5,-, 17.5)$ & $f(12.5,17.5,-, 22.5)$ & $f(17.5,22.5,-,-)$ \\
\hline $\mathrm{C} 40$ & $f(-,-, 15,25)$ & $f(15,25,-, 35)$ & $f(25,35,-, 45)$ & $f(35,45,-,-)$ \\
\hline C41 & $f(-,-, 4.5,7.5)$ & $f(4.5,7.5,-, 10.5)$ & $f(7.5,10.5,-, 13.5)$ & $f(10.5,13.5,-,-)$ \\
\hline
\end{tabular}

capabilities, middle level of control and management capabilities, and relatively poor resource ownership and innovation drive capabilities. This shows that although Port A has achieved a good foundation for development in terms of services, the construction of infrastructure resources needs to be strengthened, the scale and level of human resources in line with supply chain transformation and innovation need to be improved, and the innovation-driven development strategy needs to be implemented urgently.

It can be seen from Figure 3 that the ability level of each secondary index of Port A is in a good state. Among them, although Port A's ability to provide customers with financial services is the best among all ability levels, its own financial control ability is the worst among all ability levels. This sharp contrast shows that Port A lacks the means to "control" customers with financial instruments. Capital ties are the most effective means to "control" customers. The port's effective financial control is fundamental, and excellent financial services are only an aid.

As can be seen from Figure 4, more than half of the third-level indicators of Port A have excellent capabilities, accounting for $54.17 \%$ of the total. $39.58 \%$ of the third-level indicators are in good condition, and for the remaining $6.25 \%$, the level of ability of the three indicators is medium, which are the proportions of compound talents, the growth rate of net profit, and the debt-to-asset ratio. This once again reflects that Port $\mathrm{A}$ has poor financial control over its own financial capabilities and weaker ability to own resources, especially human resources.

Through comparison with the actual situation of Port A, it is found that the evaluation result is consistent with the actual situation of the port, which reflects the rationality and feasibility of the establishment of the evaluation index system and proves that the port capacity evaluation system constructed in this article is relatively scientific from the perspective of the supply chain. This can be used in practice to provide a reference for the operation and development of the port.

5.3.2. Suggestions for Port A Development. (1) Resource Ownership. Port A should adhere to the concept of sustainable development, further improve the construction of port infrastructure, construct an efficient port infrastructure research and development system, increase investment in the training of high-end compound talents, and build an advanced talent management mechanism. As for production resources, it is important to introduce international advanced equipment and technology, accelerate the application of new production resources, and increase the universality of new production resources. In terms of human resources, Port A should take advantage of its rich financial resources, actively introduce high-end professionals, increase investment in training compound talents, accelerate the construction of talent selection and training, use 
TABLE 5: Degree of the membership matrix for each indicator.

\begin{tabular}{|c|c|c|c|c|}
\hline Index & Gray range 1 (poor) & Gray range 2 (middle) & Gray range 3 (good) & Gray range 4 (excellent) \\
\hline $\mathrm{C} 1$ & 0 & 0.65 & 0.35 & 0 \\
\hline $\mathrm{C} 2$ & 0 & 0 & 0.69 & 0.31 \\
\hline $\mathrm{C} 3$ & 0 & 0 & 0.80 & 0.20 \\
\hline $\mathrm{C} 4$ & 0 & 0 & 0.50 & 0.50 \\
\hline $\mathrm{C} 5$ & 0 & 0.20 & 0.80 & 0 \\
\hline C6 & 0 & 0 & 0.68 & 0.32 \\
\hline $\mathrm{C} 7$ & 0 & 0.70 & 0.30 & 0 \\
\hline $\mathrm{C} 8$ & 0.20 & 0.80 & 0 & 0 \\
\hline C9 & 0 & 0.10 & 0.90 & 0 \\
\hline $\mathrm{C} 10$ & 0 & 0 & 0.74 & 0.26 \\
\hline $\mathrm{C} 11$ & 0 & 0 & 0.74 & 0.26 \\
\hline $\mathrm{C} 12$ & 0 & 0.80 & 0.20 & 0 \\
\hline $\mathrm{C} 13$ & 0 & 0 & 0.96 & 0.03 \\
\hline $\mathrm{C} 14$ & 0 & 0 & 0.80 & 0.2 \\
\hline $\mathrm{C} 15$ & 0 & 0 & 0.59 & 0.41 \\
\hline $\mathrm{C} 16$ & 0 & 0 & 0.25 & 0.75 \\
\hline $\mathrm{C} 17$ & 0 & 0.05 & 0.25 & 0.70 \\
\hline C18 & 0 & 0.10 & 0.25 & 0.65 \\
\hline C19 & 0 & 0.41 & 0.59 & 0 \\
\hline $\mathrm{C} 20$ & 0 & 0.10 & 0.90 & 0 \\
\hline $\mathrm{C} 21$ & 0 & 0.10 & 0.65 & 0.25 \\
\hline $\mathrm{C} 22$ & 0 & 0.60 & 0.35 & 0.05 \\
\hline $\mathrm{C} 23$ & 0 & 0.19 & 0.81 & 0 \\
\hline $\mathrm{C} 24$ & 0.34 & 0.66 & 0 & 0 \\
\hline $\mathrm{C} 25$ & 0.05 & 0.95 & 0 & 0 \\
\hline $\mathrm{C} 26$ & 0 & 0 & 0.32 & 0.68 \\
\hline $\mathrm{C} 27$ & 0 & 0.16 & 0.83 & 0 \\
\hline C28 & 0 & 0 & 0.15 & 0.85 \\
\hline $\mathrm{C} 29$ & 0 & 0.10 & 0.90 & 0 \\
\hline $\mathrm{C} 30$ & 0 & 0 & 0.90 & 0.10 \\
\hline C31 & 0 & 0.64 & 0.36 & 0 \\
\hline C32 & 0 & 0 & 0.10 & 0.90 \\
\hline C33 & 0 & 0 & 0.25 & 0.75 \\
\hline C34 & 0 & 0 & 0.83 & 0.18 \\
\hline C35 & 0 & 0 & 0.20 & 0.80 \\
\hline C36 & 0 & 0 & 0.30 & 0.70 \\
\hline C37 & 0 & 0.05 & 0.55 & 0.40 \\
\hline C38 & 0 & 0.30 & 0.70 & 0 \\
\hline C39 & 0 & 0.10 & 0.85 & 0.05 \\
\hline $\mathrm{C} 40$ & 0 & 0 & 0.30 & 0.70 \\
\hline C41 & 0 & 0.83 & 0.16 & 0 \\
\hline $\mathrm{C} 42$ & 0 & 0.20 & 0.70 & 0.10 \\
\hline C43 & 0.15 & 0.25 & 0.60 & 0 \\
\hline $\mathrm{C} 44$ & 0 & 0 & 0.45 & 0.55 \\
\hline C45 & 0.05 & 0.80 & 0.15 & 0 \\
\hline C46 & 0 & 0.10 & 0.65 & 0.25 \\
\hline C47 & 0 & 0.85 & 0.10 & 0.05 \\
\hline C48 & 0 & 0.05 & 0.75 & 0.200 \\
\hline
\end{tabular}

incentive mechanisms, and create a modern high-end professional talent system.

(2) Control Management. Port A should take the worldclass port's operating standards and management control system as a benchmark, strengthen financial control, and focus on information management. For financial control, Port A should establish a supply chain financial management company and financing platform, plan the top-level design of the supply chain financial business, and expand the sources of funds. It should establish a big data risk control platform for supply chain finance, based on financing platforms and third-party payment platforms, through realtime analysis and processing of transaction information, and fully implement the four-in-one analysis of capital flow, logistics, information flow, and business flow, and improve risk control rating and risk control management. For information management, Port A should use the "Internet +" thinking to realize the information interconnection between the upstream and downstream of port logistics, enhance the comprehensive information management and control 
TABLE 6: Clustering coefficients for each of the three levels of indicators.

\begin{tabular}{|c|c|c|c|c|c|c|}
\hline Index & $\mathrm{C} 1$ & $\mathrm{C} 2$ & C3 & $\mathrm{C} 4$ & C5 & C6 \\
\hline Clustering coefficient & 2.35 & 3.31 & 3.20 & 3.50 & 2.80 & 3.32 \\
\hline Index & $\mathrm{C} 7$ & $\mathrm{C} 8$ & $\mathrm{C} 9$ & $\mathrm{C} 10$ & $\mathrm{C} 11$ & $\mathrm{C} 12$ \\
\hline Clustering coefficient & 2.3 & 1.80 & 2.90 & 3.26 & 3.26 & 2.20 \\
\hline Index & $\mathrm{C} 13$ & $\mathrm{C} 14$ & $\mathrm{C} 15$ & $\mathrm{C} 16$ & $\mathrm{C} 17$ & $\mathrm{C} 18$ \\
\hline Clustering coefficient & 3.03 & 3.20 & 3.41 & 3.75 & 3.65 & 3.55 \\
\hline Index & $\mathrm{C} 19$ & $\mathrm{C} 20$ & $\mathrm{C} 21$ & $\mathrm{C} 22$ & $\mathrm{C} 23$ & $\mathrm{C} 24$ \\
\hline Clustering coefficient & 2.59 & 2.90 & 3.15 & 2.45 & 2.81 & 1.66 \\
\hline Index & $\mathrm{C} 25$ & $\mathrm{C} 26$ & $\mathrm{C} 27$ & $\mathrm{C} 28$ & $\mathrm{C} 29$ & $\mathrm{C} 30$ \\
\hline Clustering coefficient & 1.947 & 3.68 & 2.83 & 3.85 & 2.9 & 3.10 \\
\hline Index & C31 & $\mathrm{C} 32$ & $\mathrm{C} 33$ & $\mathrm{C} 34$ & $\mathrm{C} 35$ & $\mathrm{C} 36$ \\
\hline Clustering coefficient & 2.36 & 3.90 & 3.75 & 3.18 & 3.8 & 3.70 \\
\hline Index & $\mathrm{C} 37$ & C38 & C39 & $\mathrm{C} 40$ & $\mathrm{C} 41$ & $\mathrm{C} 42$ \\
\hline Clustering coefficient & 3.35 & 2.70 & 2.95 & 3.70 & 2.17 & 2.90 \\
\hline Index & $\mathrm{C} 43$ & $\mathrm{C} 44$ & $\mathrm{C} 45$ & $\mathrm{C} 46$ & $\mathrm{C} 47$ & $\mathrm{C} 48$ \\
\hline Clustering coefficient & 2.45 & 3.55 & 2.10 & 3.15 & 2.20 & 3.15 \\
\hline
\end{tabular}

TABLe 7: Clustering coefficients for each level of Port A.

\begin{tabular}{lccccc}
\hline Index & A1 & A2 & A3 & A4 & A5 \\
\hline Clustering coefficient & 2.975 & 3.027 & 3.436 & 2.955 & \\
\hline
\end{tabular}

TABLE 8: Clustering coefficients for each secondary indicator.

\begin{tabular}{lcccccccccccc}
\hline Index & B1 & B2 & B3 & B4 & B5 & B6 & B7 & B8 & B9 & B10 & B11 & B12 \\
\hline Clustering coefficient & 3.034 & 2.530 & 3.140 & 3.388 & 2.807 & 2.322 & 3.362 & 3.387 & 3.683 & 3.106 & 2.800 & 2.740 \\
\hline
\end{tabular}

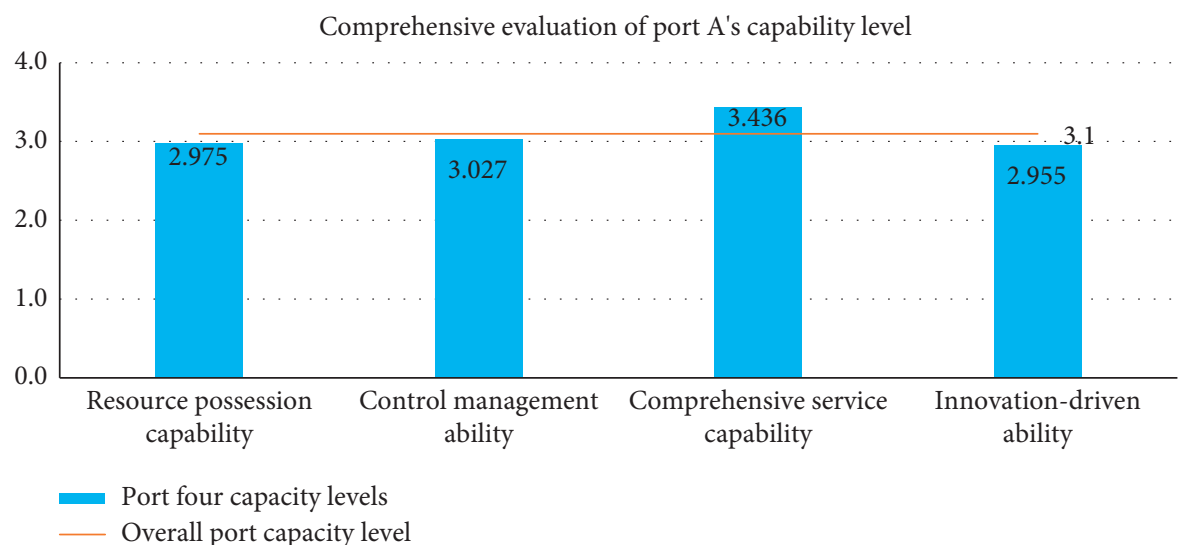

FIgUre 2: Capacity-level evaluation of Port A.

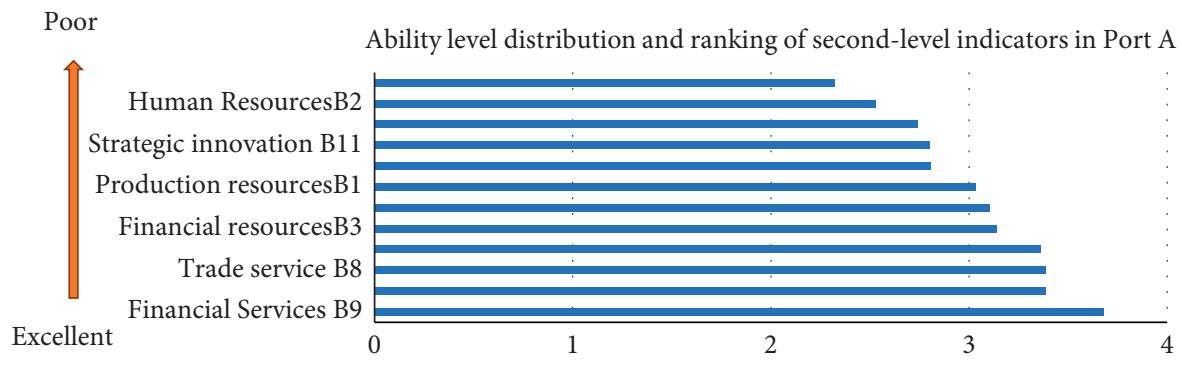

Figure 3: Capacity-level distribution and ranking chart of secondary indicators of Port A. 


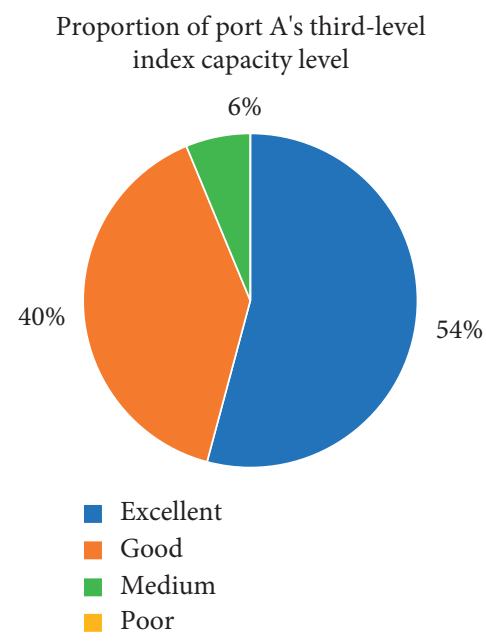

Figure 4: Proportion of tertiary index capacity level of Port A.

capabilities of Port A, and accelerate the use of advanced technologies such as the Internet of Things, big data, and cloud computing in the field of port operations. The application layout of the company promotes the construction of smart ports and smart port information application systems.

(3) Comprehensive Services. Relying on the advantages of Port A's strong service capabilities, Port A should continue to enhance the port's comprehensive service capabilities, expand its service functions, improve the basic service level of port logistics based on loading, unloading, and warehousing, accelerate the development of port logistics valueadded services, and build a port service industry chain. It should promote the development of the upstream and downstream linkages of the industrial chain and provide global target customers with professional, fast, efficient, convenient, high-quality, low-cost, and customizable full logistics services.

(4) Innovation-Driven Aspects. Port A should combine with the new economic normal, based on technological innovation, strengthen strategic innovation and institutional innovation, and lead the development of the port through innovation. In terms of strategic innovation, Port A should closely focus on the national "One Belt One Road" development strategy and promote the regional cooperation strategy of coastal ports in Northeast Asia. Regarding institutional innovation, Port A should seize the important opportunity in the construction of the national pilot free trade zone, take the development of the port trade facilitation zone as the starting point, face the Northeast Asian region, dock the pilot free trade zone system and platform, and serve free trade. It will become the hub of the free trade supply chain in Northeast Asia and realize the coordinated development of trade, logistics, finance, and economy at all ports of Port A.

\section{Conclusions}

This article is mainly a research on port capacity evaluation from the perspective of supply chain. In the process of constructing the evaluation system, although all relevant evaluation indicators are listed as much as possible according to domestic and foreign literature reports and the suggestions of teachers and experts, but it is still difficult to ensure complete exhaustion, resulting in some indicators affecting port capacity not being included in the evaluation system. Therefore, it is necessary to continuously modify and improve the index system in future research.

In addition, although the analytic hierarchy process is a combination of qualitative and quantitative methods, its assignment of evaluation indicators still has a strong subjectivity. At the same time, the quantification of qualitative indicators in this article is mainly based on the method of scoring by experts. Although mathematical statistics such as coefficient of variation and reliability analysis are used to verify it, it is still difficult to reduce the influence of subjective factors. Therefore, how to effectively weaken the subjectivity of weight assignment and quantification of qualitative indicators and make the weight coefficients of evaluation indicators and the quantified data of qualitative indicators more reasonable and objective is the focus of follow-up research.

\section{Data Availability}

The data used to support the findings of this study are included within the article.

\section{Conflicts of Interest}

The authors declare that they have no conflicts of interest.

\section{Acknowledgments}

This work was sponsored by the National Natural Science Foundation of China (grant nos. 72072112, 71602114, 72002125, and 72001135), Shanghai Rising-Star Program (grant no. 19QA1404200), Shanghai Sailing Program (grant nos. 19YF1418800 and 20YF1416600), and Shanghai Science and Technology Committee Research Project (grant no. 17040501700).

\section{References}

[1] C. Tan and J. He, "Integrated proactive and reactive strategies for sustainable berth allocation and quay crane assignment under uncertainty," Annals of Operations Research, pp. 1-32, 2021.

[2] J. H. Bird, Seaport Gateways of Australia, Oxford University Press, London, UK, 1968.

[3] J. H. Bird, Seaports and Seaport Terminals, Hutehinson, London, UK, 1971.

[4] J. Kenyon, "Elements in interport competition in the United States," Economic Geography, vol. 46, no. 1, pp. 68-82, 1970.

[5] H. M. Mayer, "Some geographic aspect of technological change in maritime transportation," Economic Geography, vol. 49, no. 2, pp. 145-155, 1973.

[6] W. Y. Yap and J. S. L. Lam, "Competition dynamics between container ports in East Asia," Transportation Research Part A: Policy and Practice, vol. 40, no. 1, pp. 35-51, 2006. 
[7] E. Haezendonck and T. Notteboom, "The competitive advantage of seaports," Maritime Policy \& Management, vol. 29, pp. 126-145, 2002.

[8] R. Banomyong, "The impact of port and trade security initiatives on maritime supply-chain management," Maritime Policy \& Management, vol. 32, no. 1, pp. 3-13, 2005.

[9] J. Tongzon, "Efficiency measurement of selected Australian and other international ports using data envelopment analysis," Transportation Research Part A: Policy and Practice, vol. 35, no. 2, pp. 107-122, 2001.

[10] M.-S. Ha, "A comparison of service quality at major container ports: implications for Korean ports," Journal of Transport Geography, vol. 11, no. 2, pp. 131-137, 2003.

[11] J. He, Y. Wang, C. Tan, and H. Yu, "Modeling berth allocation and quay crane assignment considering QC driver cost and operating efficiency," Advanced Engineering Informatics, vol. 47, p. 101252, 2021.

[12] C. M. José I, C. N. Mercedes, L. F. Gonzále, L. V. Lourdes, and M. Teresa Arévalo-Quijada, "Low-cost port competitiveness index: implementation in the Spanish port system," Maritime Policy, vol. 33, no. 4, pp. 591-598, 2009.

[13] Y. Zha, "Analysis of competitiveness of dry port based on AHP multi-layer fuzzy comprehensive evaluation," World Scientific Research Journal, vol. 5, no. 9, pp. 169-177, 2019.

[14] G. T. Yeo, M. Roe, and J. Dinwoodie, "Measuring the competitiveness of container ports: logisticians' perspectives," European Journal of Marketing, vol. 45, no. 3, pp. 455-470, 2011.

[15] C. A. Yuen, A. Zhang, and W. Cheung, "Port competitiveness from the users' perspective: an analysis of major container ports in China and its neighboring countries," Research in Transportation Economics, vol. 35, pp. 34-40, 2011.

[16] M. Wei, S. Liu, Z. Bo, and N. Xie, "Standard triangular whitenization weight function and its application in grey clustering evaluation," Journal of Grey System, vol. 24, no. 1, pp. 39-48, 2012.

[17] H. Wu and Z. Qu, "Gray clustering model based on the degree of dynamic weighted incidence for panel data and its application," Grey Systems: Theory and Application, vol. 10, no. 4, pp. 413-423, 2020.

[18] H. Gao and L. Sun, "Grey clustering evaluation of water resources carrying capacity based on triangle whitening weight function," IOP Conference Series: Earth and Environmental Science, vol. 208, no. 1, p. 012101, 2018.

[19] N. Xie, S. Bentao, and N. Chen, "Construction mechanism of whitenization weight function and its application in grey clustering evaluation," Journal of Systems Engineering and Electronics, vol. 30, no. 1, p. 121, 2019.

[20] F. Ma, J. He, J. Ma, and S. Xia, "Evaluation of urban green transportation planning based on central point triangle whiten weight function and entropy-AHP," Transportation Research Procedia, vol. 25, pp. 3634-3644, 2017. 